УДК 94(517)

БАЗАРОВ Виктор Борисович - кандидат исторических наук, научный сотрудник Института монголоведения, буддологии и тибетологии СО РАН (670047, Россия, Республика Бурятия, г. Улан-Удэ, ул. Сахьяновой, 6; bazarov_science@mail.ru)

\title{
СОВРЕМЕННЫЕ МОНГОЛО-ЯПОНСКИЕ ОТНОШЕНИЯ
}

\begin{abstract}
Аннотация. Статья посвящена современным монголо-японским отношениям. С начала 1990-х гг. Монголия проводит самостоятельную внешнюю политику, которая базируется на принципе «многоопорности». Исходя из концепции внешней политики Монголии, помимо традиционных партнеров, она имеет возможность развивать отношения с другими государствами, уравнивая тем самым влияние КНР и России. При этом из всех восточноазиатских государств Япония стала наиболее близкой “опорой» для молодой демократии Азии и возглавила организацию международной помощи Монголии. В небольшой исторический промежуток Монголия и Япония смогли нарастить двусторонние отношения до уровня стратегического партнерства. В статье автор анализирует развитие монголо-японских отношений в исторической ретроспективе, дает оценку изменениям во взаимоотношениях, характера партнерства на разных этапах.
\end{abstract}

Ключевые слова: монголо-японские отношения, «третий сосед», внешняя политика Монголии, внешнеторговый оборот, стратегическое партнерство.

Д

ипломатические отношения между Японией и Монголией были установлены 24 февраля 1972 г. С начала 1990-х гг. сотрудничество Японии и Монголии стало приобретать качественно новый характер и масштабы, стимулированные не только демократическими реформами в Монголии, но и усилением курса Японии на развитие экономического сотрудничества со странами Азиатско-Тихоокеанского региона. В годы монгольских реформ Япония стала главным международным донором Монголии. На нее приходится 1/3 объема помощи, оказываемой государству странами-донорами. Сравнительно быстро, хотя и неравномерно, растет внешнеторговый товарооборот двух стран [История Монголии... 2007: 390]. Колебания в объемах внешнеторгового сотрудничества объясняются в первую очередь медленными темпами становления рыночной экономики Монголии, ее несбалансированностью на отраслевом уровне и рядом других причин, обусловленных переходным характером современного этапа ее развития.

В 1990-е гг. в структуре японо-монгольского сотрудничества большое место занимает безвозмездная помощь японского правительства. В период с 1991 по 2013 г. правительство Японии предоставило Монголии безвозмездную помощь в размере 102,3 млрд иен, льготные кредиты в размере 77,3 млрд иен, техническую помощь в размере 36,5 млрд иен. Двусторонние отношения и сотрудничество расширяются из года в год 1 . В нулевых годах почти половина японских инвестиций была направлена в легкую промышленность Монголии, 12,6\% - в культуру, искусство и образование, $12,7 \%$ - в телекоммуникации, $5 \%$ - в транспорт, 7,4\% - в добывающую и 5\% - в пищевую промышленность. Японские гиганты, такие как Митсуи, Сумитомо, Митсубиси и Иточу, были сильно заинтересованы в инвестировании горнодобывающих проектов Оюутолгой и Тавантолгой ${ }^{2}$. Монголия, в свою очередь, поставляла сырьевой кашемир и

\footnotetext{
1 В Торгово-промышленной палате Монголии прошла встреча с делегатами города Осака. Montsame. Mongolian News Agency. 27.09.2018. Доступ: https://www.montsame.gov.mn/ru/read/165869 (проверено 10.08.2019).

2 Diplomatic bluebook 2006. Ministry of Foreign Affairs, Mongolia. 2006. C. 158-159.
} 
кашемировые изделия, которые служили основой монгольского экспорта в Японию (около 60\%), текстиль (23\%), медь (5,4\%) и др. товары.

На международной арене Монголия и Япония ведут согласованную политику в ООН, регулярно проводят встречи на высшем уровне, сотрудничают в гуманитарной сфере.

Серьезный вклад Японии лежит в области научно-технической поддержки монгольских инфраструктурных проектов, реконструкции Улан-баторской ТЭЦ-4, а также в поддержке объектов социально-экономического значения. В 10 аймаках осуществлен капитальный ремонт и оснащены новейшим учебным оборудованием общеобразовательные школы, поставлена партия автобусов для общественного транспорта Улан-Батора, построен комбинат по производству кашемира Гоби, продукция которого стала брендом национального производства Монголии. В рамках программы «Корень травы» реализуется ряд проектов в отраслях аграрного сектора, животноводства. Постепенно помощь Японии из сферы обслуживания и услуг перемещается в разработку минеральных ресурсов, строительство дорог, объектов энергетики, развитие коммуникаций. В числе новых проектов - строительство крупного международного аэропорта. Расширяется сотрудничество в области развития человеческого ресурса, т.е. в образовании, здравоохранении, обеспечении населения чистой водой и т.д.

В начале нулевых годов нарастает межправительственный диалог. Так, премьер-министры двух стран встречаются с периодичностью раз в 4 месяца. Следует подчеркнуть, что столь регулярного контакта у монгольского руководства нет ни с одной другой страной.

При анализе данных внешнеторговых отношений Монголии и Японии за период 2005-2013 гг. видно, что доля японского товарооборота довольно низка, но наблюдается постоянный рост с редкими падениями, обусловленными снижением всего торгового оборота Монголии из-за последствий экономического кризиса 2008 г. ${ }^{1}$ Также видно, что и экспорт, и импорт демонстрировали стабильный рост, за исключением упомянутых выше падений.

Стабильное развитие торгово-экономических отношений продолжается на фоне активных двусторонних дипломатических отношений. 9-11 февраля 2015 г. премьер-министр Монголии Ч. Сайханбилэг находился с официальным визитом в Японии. В результате переговоров с премьер-министром Японии Синдзо Абэ было подписано Соглашение о монголо-японском экономическом партнерстве ${ }^{2}$, что придало новый статус монголо-японским отношениям: теперь они будут рассматриваться в рамках стратегического партнерства. 22 октября 2015 г. премьер-министр Японии Синдзо Абэ прибыл в Монголию с официальным визитом. Был подписан межправительственный меморандум о сотрудничестве в реализации проектов строительства железнодорожной линии на восток от месторождения Тавантолгой и других соответствующих инфраструктурных проектов.

12-15 октября 2016 г. премьер-министр Ж. Эрдэнэбат находился с официальным визитом в Японии. В рамках визита прошли официальные переговоры с премьер-министром Синдзо Абэ. В совместном заявлении не раз подчеркивались важность и приоритетность монголо-японских отношений для Монголии. Стороны договорились разработать новую среднесрочную программу по развитию монголо-японского стратегического партнерства в 2017-2021 гг., отразив в ней ключевые направления деятельности на предстоящие 4 года.

\footnotetext{
${ }^{1}$ Монгол Улсын статистикийн эмхтгэл. 2013 [Статистический сборник Монголии]. Улан-Батор. 2014. C. 274.

2 Монгольский кашемир и водка готовятся покорять Японию. - Asia Russia Daily. 26.10.2015. Доступ: http://asiarussia.ru/news/9638/ (проверено 23.08.2019).
} 
30 августа 2017 г. в г. Улан-Баторе состоялась трехсторонняя встреча представителей министерств иностранных дел Монголии, США и Японии. Формат этого мероприятия представляет собой платформу по обмену мнениями по вопросам международного, регионального сотрудничества и экономической интеграции Монголии, Японии и США. В этот раз представители Японии и Соединенных Штатов выразили надежду, что Монголия полностью выполнит свои обязательства, согласованные с МВФ в рамках реализации расширенной программы финансирования. Японская и американская стороны отметили конкурентные преимущества монгольского сельскохозяйственного сектора и выразили желание сотрудничать с Монголией в реализации проектов в области возобновляемых источников энергии ${ }^{1}$.

6-7 сентября 2017 г. президент Монголии Х. Баттулга принял участие в Восточном экономическом форуме в г. Владивостоке. В первый же день форума он встретился с премьер-министром Японии Синдзо Абэ. В беседе стороны обсудили вопрос создания в порту региона Дальнего Востока совместной хозяйственной единицы по поставке коксующегося угля из угольного месторождения Тавантолгой. Премьер-министр Синдзо Абэ предложил наладить тесное сотрудничество в области обороны, в т.ч. в решении северокорейской проблемы. Отметив, что правительство Японии решило предоставить Монголии долгосрочный кредит в размере 850 млн долл. США, Синдзо Абэ подчеркнул, что он поддерживает проводимую Монголией политику по обеспечению выхода к морю, по поддержке баланса во внешней политике и расширения экономических связей ${ }^{2}$.

21-25 февраля 2018 г. министр иностранных дел Монголии Д. Цогтбаатар посетил Японию с официальным визитом с целью укрепления политических отношений с Японией, расширения экономического сотрудничества и обеспечения реализации Среднесрочной программы по стратегическому партнерству (2017-2021 гг.) и Соглашения об экономическом партнерстве 3 . Также в рамках визита министр иностранных дел Д. Цогтбаатар провел встречи с министром экономики, промышленности и торговли Японии Хиросигэ Сэко, с вице-президентом Японского банка международного сотрудничества Т. Маэдой ${ }^{4}$ и принял участие в монголо-японском бизнес-форуме 5 .

26 апреля 2018 г. в г. Токио состоялась трехсторонняя встреча представителей министерств иностранных дел Монголии, Японии и США. Монгольскую делегацию на этой встрече возглавил госсекретарь МИДа Д. Даваасурэн, американскую сторону - исполняющая обязанности помощника госсекретаря по делам Восточной Азии и Тихого океана госдепартамента США г-жа С. Торнтон, японскую сторону - генеральный директор департамента по АзиатскоТихоокеанскому региону МИДа Японии К. Канасуги. Стороны обменялись мнениями по вопросам обеспечения мира и стабильности в регионе СевероВосточной Азии: денуклеаризации Корейского полуострова, координации деятельности по вопросам общих интересов на международном и региональном

\footnotetext{
${ }^{1}$ Монголия будет сотрудничать с США и Японией в области ВИЭ. - Montsame. Mongolian News Agency. 31.08.2017. Доступ: https://www.montsame.gov.mn/ru/read/161201 (проверено 10.08.2019).

2 Премьер министр Японии Синдзо Абэ нанес визит Президенту Монголии. - Montsame. Mongolian News Agency. 06.09.2017. Доступ: https://www.montsame.gov.mn/ru/read/161226 (проверено 10.08.2019).

3 Глава МИД Монголии совершит официальный визит в Японию. - Montsame. Mongolian News Agency. 19.02.2018. Доступ: https://www.montsame.gov.mn/ru/read/162720 (проверено 10.08.2019).

4 Глава МИД провел ряд встреч с представителями японских организаций. - Montsame. Mongolian News Agency. 26.02.2018. Доступ: https://www.montsame.gov.mn/ru/read/162787 (проверено 10.08.2019).

5 Глава МИД Д. Цогтбаатар принял участие в монголо-японском бизнес-форуме в Токио. Montsame. Mongolian News Agency. 27.02.2018. Доступ: https://www.montsame.gov.mn/ru/read/162797 (проверено 10.08.2019).
} 
уровнях. Также японская и американская стороны выразили готовность поддержать Монголию в региональной интеграции ${ }^{1}$.

11-13 сентября 2018 г. во Владивостоке состоялся IV Восточный экономический форум (ВЭФ), в котором приняли участие президент Монголии Х. Баттулга, президент России В.В. Путин, председатель КНР Си Цзиньпин, премьер-министр Японии Синдзо Абэ, премьер-министр Республики Корея Ли Нак Ен и др. В рамках форума президент Монголии Х. Баттулга провел встречу с премьер-министром Японии Синдзо Абэ. Президент Монголии выразил заинтересованность в создании энергетической суперсети СевероВосточной Азии, расширении сотрудничества с Японией в сферах туризма, сельского хозяйства и строительства экогорода. Стороны обменялись мнениями по вопросам экономического сотрудничества, увеличения объема экспорта Монголии в Японию и обеспечения региональной безопасности ${ }^{2}$.

13 декабря 2018 г. премьер-министр Монголии У. Хурэлсух и премьер-министр Японии Синдзо Абэ провели официальные переговоры в г. Токио. Из 14 пунктов совместного заявления следует выделить договоренность о дальнейшем укреплении стратегического партнерства между двумя государствами, презентацию хода реализации Среднесрочной программы стратегического партнерства. Также премьер-министры двух стран выразили надежду, что новый международный аэропорт в г. Улан-Баторе станет символом сотрудничества и сыграет важную роль в расширении контактов между народами Монголии и Японии. Главы правительств согласились сотрудничать в области реализации инициативы «Свободный и открытый Индийско-Тихоокеанский регион», которая нацелена на поддержку интеграции, открытое развитие и сотрудничество между государствами региона ${ }^{3}$.

19 апреля 2019 г. министр труда и социальной защиты С. Чинзориг и министр юстиции Такаши Ямашита подписали меморандум о взаимопонимании для совместной реализации рабочей силы из Монголии. Этот меморандум позволяет гражданам Монголии работать в равных трудовых условиях с японцами на территории Японии. Напомним, что в 2018 г. Монголия вошла в число 9 стран, которым разрешено поставлять в Японию рабочую силу в соответствии с пересмотренным законом об иммиграционном контроле. Граждане Монголии имеют возможность устроиться на работу в 14 секторах, таких как строительство, гостиничный бизнес, сельское хозяйство, медицина, судостроение и пр. ${ }^{4}$

Таким образом, монголо-японские отношения, официально стартовавшие около полувека назад, реальное развитие получили только в постсоветский период. Монголия в переходный период, как и большинство стран бывшего соцлагеря, испытывала кризис как экономического, так и политического характера, сопровождаемый идеологическим сломом старых форм идентификации страны в новом мире. Япония получила прекрасный исторический шанс реализовать себя на освободившемся от влияния Советского Союза пространстве. Она возглавила донорскую помощь Монголии и вовлекла в оборот этого

1 В Токио состоялась трехсторонняя встреча представителей Монголии, Японии и США. Montsame. Mongolian News Agency. 27.04.2018. Доступ: https://www.montsame.gov.mn/ru/read/163420 (проверено 10.08.2019).

2 Президент Х. Баттулга провел встречу с премьер-министром Японии Синдзо Абэ. - Montsame. Mongolian News Agency. 12.09.2018. Доступ: https://www.montsame.gov.mn/ru/read/164491 (проверено 10.08.2019).

3 Премьер-министры Монголии и Японии выступили с совместным заявлением по итогам переговоров. - Montsame. Mongolian News Agency. 14.12.2018. Доступ: https://www.montsame.gov.mn/ru/ $\mathrm{read} / 174387$ (проверено 10.08.2019).

4 Япония нуждается в рабочей силе из Монголии. - Montsame. Mongolian News Agency. 19.04.2019. Доступ: https://www.montsame.gov.mn/ru/read/186782 (проверено 10.08.2019). 
движения другие развитые страны. Не снижая принятых темпов в организации безвозмездной помощи и льготного кредитования, Япония стала внимательно изучать геополитические и геоэкономические перспективы своих дальнейших действий, усиливая свои взаимоотношения не только за счет известных инициатив гуманитарного содержания, но и путем комплексной системы подготовки и переобучения квалифицированных кадров.

В 1990-е гг. неспешный внешнеполитический диалог между Монголией и Японией сопровождался поступательным увеличением торгового оборота между этими странами и постоянным вливанием японской финансовой помощи, инвестиций в экономику Монголии. При этом японские инвестиции носили инфраструктурный характер с постепенным вовлечением новых объектов горнорудной промышленности Монголии. Постепенно шло нарастание внешнеполитического диалога между государствами, что увеличило доминанту Японии во внешней политике Монголии как основного «третьего соседа».

В нулевых годах монголо-японские отношения выстраиваются в русле стратегического партнерства, раскрывается геополитическая роль Монголии как равноправного и важного союзника в регионе Северо-Восточной Азии. Монголия для Японии становится посредником и в северокорейском вопросе, необходимым партнером в обеспечении безопасности в регионе.

\begin{abstract}
Статья подготовлена в рамках государственного задания (проект ХІІ.187.1.4.«ХII.191.1.2. «Межкультурное взаимодействие, этнические и социально-политические процессы в Центральной Азии», номер госрегистрации № $A A A A-A 17-117021310264-4)$.
\end{abstract}

\title{
Список литературы
}

История Монголии. ХХ век (под ред. Р.Б. Рыбакова). 2007. М.: Институт востоковедения РАН. 448 с.

BAZAROV Victor Borisovich, Cand.Sci.(Hist.), Researcher at the Institute of Mongolian, Buddhist and Tibetan Studies, Siberian Branch of the Russian Academy of Sciences (6 Sakhyanovoj St, Ulan-Ude, Republic of Buryatia, Russia, 670047; bazarov_science@mail.ru)

\section{MODERN MONGOLIAN-JAPANESE RELATIONS}

\footnotetext{
Abstract. The article is devoted to modern Mongolian-Japanese relations. In the post-Soviet period, Mongolia pursues an independent foreign policy, based on the principle of multi-pillar. In addition to traditional partners, in modern conditions Mongolia has the opportunity to develop relations with other states in order to balance the influence of China and Russia. Japan during the democratic period became the closest pillar for the young democracy of Asia. Japan has become the leader in organizing international assistance for Mongolia throughout the entire period of formation and development. In a small historical period, Mongolia and Japan were able to build up bilateral relations to a strategic partnership. The article analyzes the development of Mongolian-Japanese relations in historical retrospective.

Keywords: Mongolian-Japanese relations, third neighbor, Mongolia's foreign policy, foreign trade turnover, strategic partnership
} 